\title{
口蓋裂術後の高度鼻咽腔閉鎖機能不全症の外科的治療
}

\author{
西村 善彦・雲井 健雄
}

\section{Operative Procedure for Grave Velopharyngeal \\ Insufficiency after Cleft Palate Surgery}

\author{
Yoshihiko Nishimura and Takeo Kumoi \\ (Hyogo College of Medicine)
}

To achieve an effective velopharyngeal valval mechanism for patients with abnormalities of speech related to ineffectual velopharyngeal function, we adopted the repush back and levator sling reconstructive operation combined with pharyngeal flap. The cut of the nasal side of the soft palate can easily contact the posterior pharyngeal wall. The raw nasal surface behind the bony end up to the lateral walls completely covered the upper based posterior pharyngeal flap to prevent the wound contraction. This flap does not make the naso-pharyngeal space narrow but mainly covers the raw area. Simaltaneously, the levator sling reconstruction is performed by retropositioning of the levator muscles. Almost all of cases showed lengthened soft palate and good mobility necessary for speech.

Key words: cleft palate, velopharyngeal insufficiency, pharyngeal flap

はじめに

口蓋裂手術交行ったにもかかわらず言語に障 書走遺す例は近時著しく隇少した。しかしきわ めて高度な鼻咽腔閉鎖機能不全状態を呈して言 語明膫度少悪な例屯依然として存在する。正常 言語を発しうるための諸条件の中で, 鼻咽腔の 閉鎖機能, とりわけ弁機能 (valve function) は最む重要なむのである。鼻腔と口腔との遮断 機能の少腎な症例に訓練のみによる言語の改誓 を期待するのは無䭾である．まず外科的手段に よって鼻栶腔の弁構造を解剖学的に正常に近い 状態に変損し，しかる後に言語訓練が課せられ るべきものである．乙のような例への外科的手 段として代表的な方法 ${ }^{12) 3}$ は咽頭弁手術と re- push-back 法とである. 前者は鼻咽頭容積の縮 小と閉鎖の補助が目的であって，本来の組織の 閉鎖機能の向.ヒが計られるものではなく，生理 的には不自然な㯇造物を作る術式であり，閉鎖 機能の極端に覀い例には效果少なく ${ }^{4)}$ ，適応は 限られる，後者は口側の後方移動によって生じ た㴰栶磌粘膜側（以下鼻側という）の開放創の 収綰により, 術直後の状態を維持することは不 可能に近く，所期の目的を達するような結果は なかなかえられない。

我々がここに示す術式は粤倒粘膜を口盖骨後 縁よりやや後方でこれにほぼ平行な離断を行 い，乙の切開を畺咽頭側壁に至るまで延長し， 思い切り軟口蓋を後方へ移動し，生じた鼻側の 
略三角形の開放創を咽頭弁を用いて被覆充填 し，その弁の茎は裹面開放创のままとして最終 的に鼻咽頭部に残る異常構造物の縮小をはかる あのであり, 同時に挙筋の後方移動処理之残存 洀痕組織の可及的除去を行い, 解剖学的に正常 構造に近い軟口蓋を再建するものである．現 在, 術後半年以上経過し, 本法の効果を判定し うるむのは11例にすぎないが, 従来の方法に比 べ成績は良好である，今回はその術式について 報告する。

\section{術式}

1. 軟口蓋を正中離断する，硬口蓋部にW型 の粘县膜弁を作り，それを起こす。この弁は大 口蓋動静脈・神経束を含み，その荃を $15 \mathrm{~mm}$ 以上 引き出す。口蓋骨後縁を確認し，その鼻側を豩 離して後縁を充分露出した後, 軟口蓋に続く鼻 咽頭側壁を翼乫起内側面，耳管開口部近くまで 粘骨膜上を剝離する。軟口蓋を正中離断し，そ の切断面老触診して, 硬い粮痕組織を可及的に 除去する.

2. 口蓋骨後縁尾側約 $2 \mathrm{~mm}$ の位置に, 後縁と 平行な切開を加え，乙れを鼻咽韻側壁移行部か らわずかにそれを越した位䈯にまで進める。乙 れにより軟口蓋は思い切り後方への移動が可能 になる。

3. 軸椎々体前部に先端をむち, 幅 $15 \sim 20 \mathrm{~mm}$ の咽頭粘膜・上咽頭収縮筋を含んだ短冊状の弁 （以後咽頭弁之呼ぶ）在椎体前部縦走膜上の踈 な結合組織より起し，咽頭扁桃部に達する. 弁 挙上後の創面は一次縫緶する。起こした咽頭弁 の先端を軟口蓋横断端中央部に縫着し, 順次断 端面に縫いつけ咽頭側面に至る。咽頭弁の先端 の二角が丁度鼻咽頭側壁の粘骨膜欠損部を閉じ るととになり軟口蓋鼻側の前半部は咽頭後壁の 組織でおきかわったととになる。

4. 口蓋骨後端およで披裂縁に無処理のま ま，あるいは処理不十分のままで附着している 口蓋帆挙筋（以後挙筋と呼ぶ）は後方へ移動さ れた軟口蓋にふくまれているが，軟口蓋の挙上 運動の中心点をより尾側へ移動させるために,
筋束を少し剝離して筋体を確実に端々吻合す る．その操作の前に口蓋垂の形成，軟口蓋鼻側 粘膜の縫合が行われる.

5. 口側粘骨膜弁を数力所「8」の字縫合す る。その系は咽頭弁をむすくうことで粘骨膜弁 後方移動が確実に達っせられる．乙のとき軟口 蓋が容易に咽頭後壁に搈することを指で確認す る.

6。移動により生じた臼菡部菡槽哭起舌侧の 骨露出部は才キシセルなどの止血材料を充填し て手術を終了するが，骨露出面積のきわめて広 い場合には，日後部に茥をむった田齒部唇側搷 粘膜弁を移動してその一部を閉鎖するとともあ る.

以上の操作により軟口蓋の洀痕組織除去, 挙 筋後方移動，㹬口蓋粘骨膜弁後方移動による軟 口蓋延長，それにより生じた軟口蓋鼻側開放剳 の咽頭弁による被樭などの処理がなされたこと になる。

\section{考察}

口蓋裂術後の言语が正常か否かの判定はおよ そ 4 才の時点でなされる ${ }^{516)}$. この時期には幼児 語の混在はあるが構音が正常であるか否か，そ の原因が丵咽腔の弁閉銷機能の不全によるか, あるいは構音動作のみの異常であるかの診断が 可能である．後者の場合は構音の指筫によって 治療しうるはずであるし，前者の場合であ軽症 例では適切な指導と訓練によって相当の改善が なされうるといい7)，言語治療の意義は大きい わけである。とてろがきわめて高度な機能不全 の症例を言語治療士あるいは音声言語病理学者 にその治療をゆだねるのは筋違いであるといわ ねばならない。しばしば長年にわたって訓練を 続けているてれらの症例をみることがあるが， 依頼した医阿む，治療を引受けている訓練士も 無責任のそしりはま妨扏ない.

ところで，何をむって高度の鼻咽腔閉鎖機能 不全症と診断するか，その規準がまず論ぜられ るべきである，ところが鼻咽腔の閉鎖機能，亡 くに言語の状態を他覚的に評価する普遍的な方 


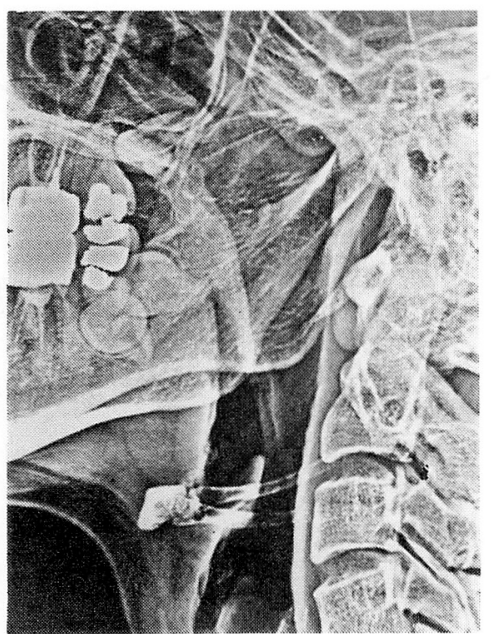

a

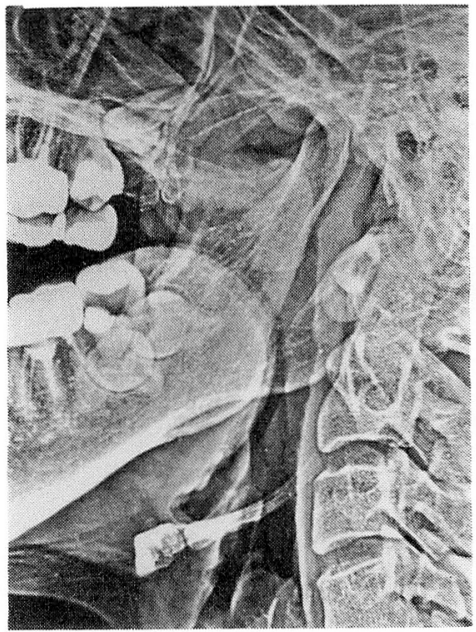

b

図Ｉ正常者の㝠咽腔側面ゼログラム

a は安静時，bは動作時（「ア」発声時）正常軟口蓋は正面正視 頭位で安静時には第二䪹椎々体中央部に先端が達し, 舌根を覆う ように位置しており，動作時（「ア」発声時）には中央部よりや や尾側が耳管咽頭口尾側（耳管隆起）の方向へ「く」の字型に挙 上される.このとき咽頭側壁が正中移動して左右より腔を狭め閉 鎖をより完全にする。乙れら一連の動きの主役は側頭骨岩様部を 起始としハンモック状に走行する口蓋帆挙筋の収縮運動に他なら な(17) 18).

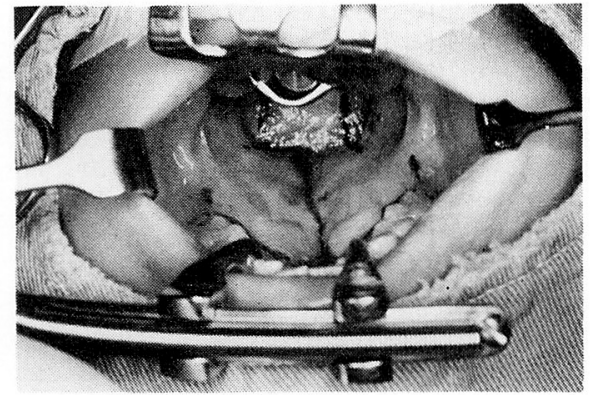

a

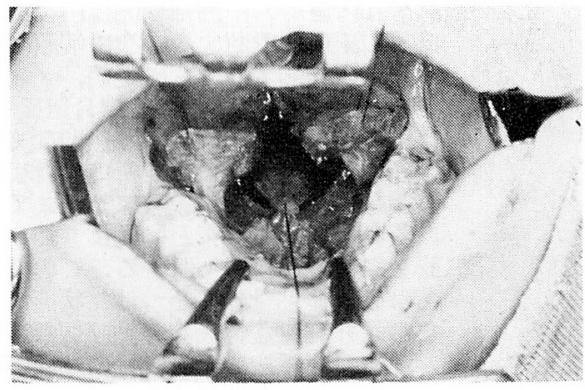

b

図 2 


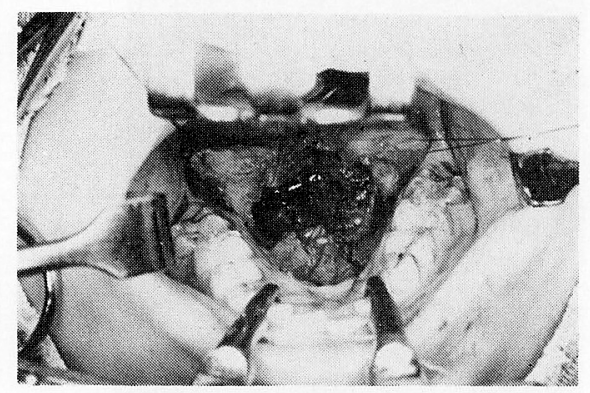

C

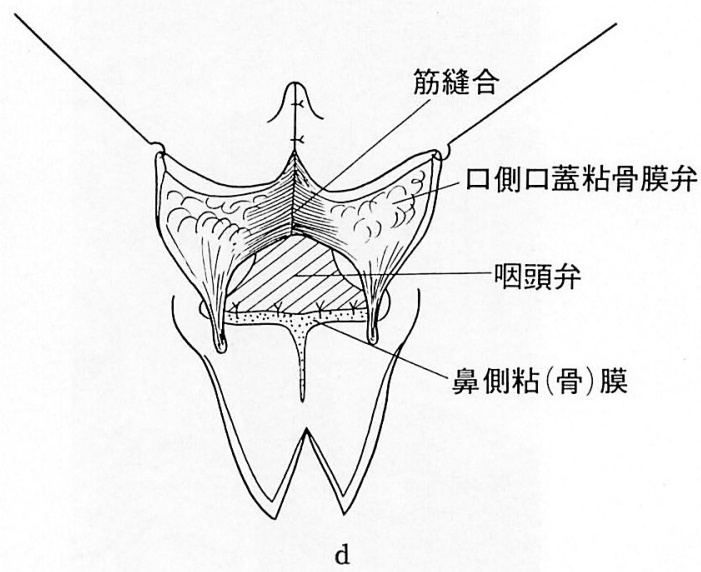

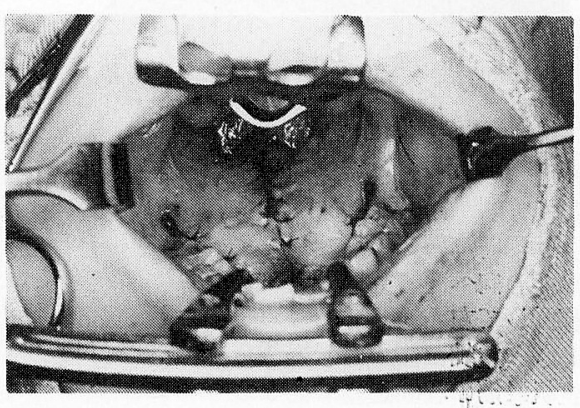

e

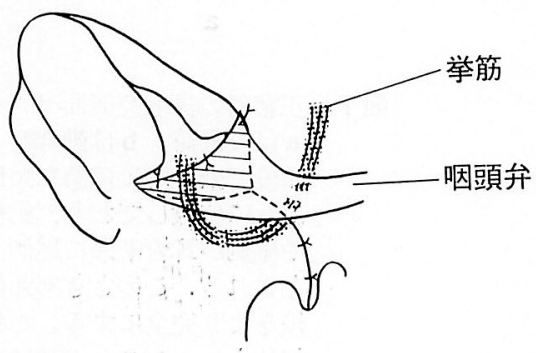

f

図 2 本法術式解説図

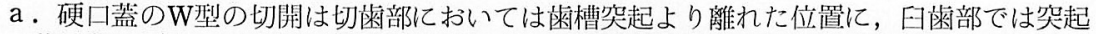
移行部に置く．田歯部切開は巨後部をまわり蝶形骨翼突起内側板先端付近に達する。軟 口蓋の正中を離断する. 次に咽頭後壁に上茎法の咽頭弁を作図する.并の先端は開口器 舌圧子の先端よりさらに尾側, メスの届く最深部にとり（第三頸椎々体部にかかるあた り), 縦走する椎体前部硬結合組織 (煩咽頭笳膜)上の粗結合組織汃ら起こす. 弁の長さ はその先端が硬口蓋後縁に無理なく届く位置までとする，通常，咽頭扁桃尾側にあたる。 b. 硬口蓋粘骨膜弁を起し, 口蓋骨後縁を確認する。鼻側粘骨膜を口蓋骨後縁から両側の 翼突起内側板の粘骨膜下に至るまで剝離する. 翼突鈎の根部を，ミで骨折させた後，大 口蓋動静脈・神経束を同孔よりしごき出す. 15〜20mmの茎は必要である. 次に鼻側粘骨 膜を口蓋骨後縁で切断する。この切開は両側の咽頭側壁にかけて進む.てれにより軟口 蓋は硬口蓋粘骨膜弁をつけた状態で思い切り尾側への移動が可能となる．次に a で起し た咽頭弁を口蓋骨後縁の粘膜切断端に縫合固定する.

c . 咽頭弁を順次口蓋骨後縁の粘膜切断端および咽頭側壁の粘骨膜切断端に縫着し咽頭側 の上皮久損部を閉鎖する.

b . c の模式図である.幅 $20 \mathrm{~mm}$ 咽頭弁を後奥孔下壁およびわずかに側壁に至るまで展開 縫着する。口蓋帆挙筋は通常無処理のまま口盍骨披裂縁に付着した状態にあるから硬軟 口蓋の境界部が完全に離断されれば，筋は後方へ移動された軟口蓋組織に含まれ，軟口 蓋正中離断面の再縫合にって举筋の吊り輪状走行が形成される.

e . 軟口蓋先端部 (口蓋垂の根部) 思い切り尾側へ案引儿咽頭後壁に一時的に縫合固定 した後, 硬口蓋粘骨膜弁の正中離断部を瘑着する。再建された軟口蓋中央部の数力所を $\lceil 8 」 の$ 字縫合して, 縫着を強固なものとするとともに，その糸は咽頭弁を稚実につか んで, 死腔の防止と軟口蓋後方移動の維持に役立たせる、硬口蓋の骨露出部はオキシセ ル等の止血材料で充填する。罒後部の開創は，もし組織に余裕があれば縫合するが，こ れは再建軟口蓋の可動性を阻害しない限りにおいてのみ行う.

f . 術終了時の状態を咽頭側からみた模式図である。咽頭弁の茎以外は解剖学時に正常に 返い形態が完成されたととを示す. 

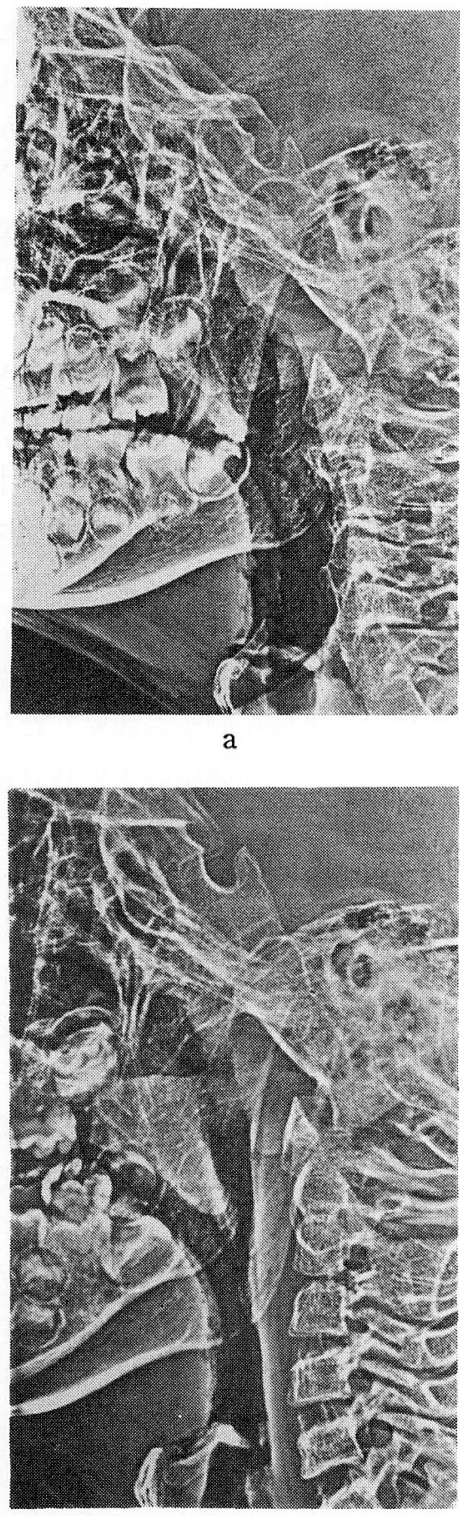

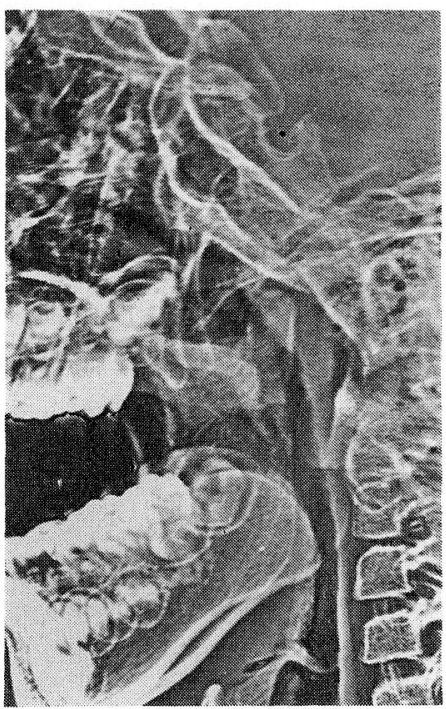

$\mathrm{b}$

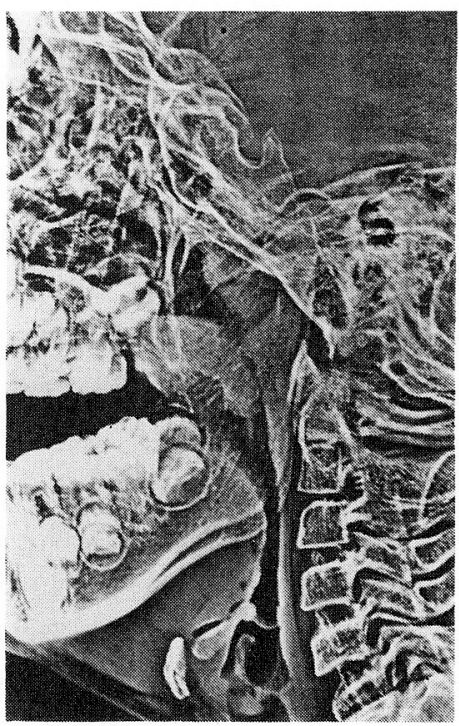

d

図 3 高度鼻咽腔閉鎖機能不全例（8才方）の手術前後の側面ゼログラム。 a . 術前安静時, 軟口蓋はきわぬて短い.

b . 術前「ア」発声時，軟口蓋は菲薄でしかも咽頭後壁間に相当の間隙を 有し，弁閉鎖状態はきわめて悪いことが示される.

c . 術後 6 ケ月の安静時, 軟口馌は延長され，しかも充分な厚みをもって いることは筋層が再編されたことを示している，咽頭弁の茎が軟口蓋 中央より吻側に位置しているのがわかる．咽頭弁の軟口蓋附着部と口 㥺骨後縁との距離が後方移動の行われた距離になる。

d.「ア」発声時, 弁閉鎖は確実に行われ, 咽頭弁の附着部のやや尾側が 挙上点となり, 挙筋後方移動の效果が示され, 咽頭弁の茎は軟口㥺挙 上・升閉鎖運動の障㫪になっていないてとも示されている。この症例 の語音明瞭度は著明に改善された。 
策はまだない，鼻咽腔閉鎖機構は括約状の閉鎖 と弁閉鎖とからなり，前者は嚥下時に気道を消 化管から分離するという原始的な装置としてあ り, 後者は語音産生のための高度な, しかも学 習によって獲得される機構として存在し, 雨者 は互に代償し合う部分を共有するという関係に ある。したがって閉鎖機能と言語明瞭度が必ず しも密な相関を示さない。しかしそれらは構造 上はほぼ正常に近い状態，ないしは代償しうる 状態にある鼻咽腔において生ずる問題であっ て，明らかに弁としての長さが足りない軟口蓋 で，パッサーバン隆起や鼻咽腔側壁の収縮を持 ってしても口腔と鼻腔を完全には遮断出来ない 状態にあるものは言語明膫度は確実に悪く, 特 有の言語を発するはずである。乙れを高度の䁷 咽腔閉鎖機能不全症（口蓋裂術後の）とする.

弁閉鎖機能の評価法 ${ }^{8)}$ あるいは病態把握法" として次のようなものがある１）空気力学的 検查（pneumotacogramによる口腔内压と経 鼻漏出気流量との比がしばしば指標となる).

2) X線撮影（高压あるいは造影ビデオなど）.

3 ）鼻咽腔ファイバースコピーによる钼察.

4 ）音声解析 (sound spectrogram).5) 単 語, 文章の明暸度による構音評価，6）口腔内 の視診触診、乙れらの結果を総合して鼻咽腔の 閉鎖状態が判断される。

本庄 ${ }^{(0)}$ は言語訓練の限界点の一つの基準とし て pneumotacogram による鼻咽腔抵抗值 50 dyne・sec $/ \mathrm{cm}^{5}$ をあげている。口蓋裂術後患者 で50 dyne・sec $/ \mathrm{cm}^{5}$ 以下の口腔内所見は，それ を裏付ける状態が視診によって碓認される，高 度䁷咽腔閉鎖機能不全症がこれである。すなわ ち，きわめて短い，そしてしばしば口蓋垂を欠 く軟口蓋で, この軟口蓋は「ア」発声時に口蓋 骨後緑に近い部分のみが収縮し，筋運動が軟口 蓋の挙上運動に結びつかず，口蓋垂筋の収縮に よる表現が優位となり，運動時に軟口蓋が短縮 するだけで，咽頭後壁との距離はますます遠ざ かる状況にある，同時に臼後部から前口蓋弓に かけて索状拘縮をみるのもこのような例におい
てであり，ときにパッサーバン隆起が著明であ り，それは挙上された軟口蓋後端よりあ尾側に 観察される例を年長児でみることがある．触診 してみると，乙の軟口蓋は正中縫合部が瘢痕か らなり，弾力性を欠いた硬い組織であるととも 分かる、レントゲン撮影により,静止時と「ア」 発声時との状態を側面像でみると, 軟口蓋はき わめて短小で, 運動時にもその動きは弱く, 咽 頭後壁との間陌は広くしかす挙上点は前方に偏 位し，弁としての構造も運動も不十分であるて とが示される．との状態の把握にはゼログラム やF C Rが有効であり，特に前者は軟部組織の 解像度が高く, 筆者らの好んで用いる撮影法で ある.鼻咽腔ファイバーを外鼻孔から插入して 閉鎖状沉を後鼻孔側から観察したり，X線造影 ビデオを見て咽頭側壁の正中移動運動を観察す るととむ行われる.

ところで正常な軟口蓋は安静時には軸椎々体 中央部に達し, 舌根を打沶うように位置してお り,「ア」発声時には耳管咽頭口に向けて「く」 の字型に収縮挙上される (図1) 之同時に, 相 当な厚みをむっているが柔らかく，俊敏な運動 をてなすと同時に口腔と鼻腔を閉鎖する弁とし て高い压に耐える組織である，高度不全症の軟 口蓋は，長さに拈いて全く弁としての役制をは たしえないむのである．この状態が開鼻声を生 ぜしめ，それを代償する特有の異常構音（glottal stop, pharyngeal fricative など）を生 み, サ行力行の判別不能で文章音読の明暸度が 極めて悪いものとしている原因である。乙の高 度鼻咽腔閉鎖機能不全症の言語明膫度を上げる には，まず賁咽腔の構造を解剖学的に正常に近 い状態に換えひきついで言語治潦士による構 音の改良がなされるべきがあると考える。「手 術, しかる後に訓練」でなりればならない。手 術は, 軟口蓋の増量による延長と, 挙筋の後方 移動とが目的である。

咽頭弁手術は Schonborn (1875年), Rosenthal (1924年) 以来, 鼻咽頭容積の縮小之鼻咽 腔閉鎖の補助装置としての構造物として意味を 
あってきた。したがってての弁の茎部裏面開放 創の術後収縮治㾑による容積減少を防ぐため に，弁を简状俄としたり重ね弁 ${ }^{1213)}$ としたりの 工夫がなされてきた，筆者らはててで発想の変 換を行い，まず咽頭弁を軟口蓋鼻倒の延長材料 として用い，乙の㚏の荃は延長增宣に必要な組 織の篓鉒供給路としての意義を有するあのであ って，例治瘉に要するたかだか 2 週間の生存を 期待するのみでよいと考えた。事尖，ての荃は 術後 1 ケ月には太さ $5 \mathrm{~mm}$ 以下の索状物となって いることが多い。術後に軟口羙の登上運動の力j 向を钼祭し，むし屯萎綰残存せる茎がそれを俳 限していると判楽されるような满合には，茎の 切断をむ考虑している.

咽頭弁手術と共に re-push-back 手術屯本症 の手術法の代表的なものの一つとして歴史をも っている，现在口蓋裂一次手術は，奏態はどう であれ push-back 法全盛である。したがって, 今我々が目の前にしている口蓋裂術後の高度番 咽腔閉鎖機能不全症の口蓋は push-back 術後 のものであり，そこから re-push-backなる名 称が与えられたのわけである. push-backは畄 側粘膜の横切離䉼によってきわめて効果的に達 せられるあのである(14)。しかし，生じた鼻側の 開放創を二期癒合にまかせて治沼せしめれば， 一旦は後方へ移動されたかに思えた軟门蓋は再 び元の位圆近くまで戻り，しかむ鼾側は瘢痕性 拘縮を伴い所期の目的在達するととがむつかし い，そこで，弁としての必要にして充分な組織 量が軟口蓋に与えられたてとによって生じた後 鼻孔尾側の開放創面を頭側に基部老屯つ咽頭弁

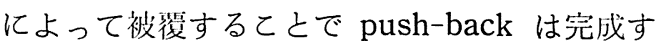
る. 成人の後鼻孔横径は $30 \mathrm{~mm}$ 前後であるから， 被鳆されるべき開放例の橫径はそれ以上となる が，幅20mmの栶頭弁はそれを㠅うに充分であ る。小児なら $15 \mathrm{~mm}$ 幅の茎で問に合う。いずれも 弁採取部の一次縫維は可能である。口蓋裂術後 の構音異常は注として軟口瓂の形態的機能的異 常によるあのであるが，ま机に先天性挙筋形成 不全によるものと思われる例をみることがあ
る．挙筋の状態は咽頭側壁の正中移動運動を観 察するととによって知ることができる ${ }^{15)}$ との ような例には本法は適忍とならない.

本術式により Pneumotacogram 测定值は $\infty$ となり，閉鎖機能については目的を達するが， それのみで直ちに言語が环常になるむのではな い，術直後閉鼾声となるが一時的である，耳管 機能不全，血性鼓膜となるが通気により漸次正 常化する．３ ケ月を過ぎて侧治癒機構が完了 し，軟口蓋の可動性が良くなってから構音の指 寀に入る，7才までの小児においての言語正常 化はすみやかであるが，年長児においては構音 動作の琹習慣から開放されるのに相当の期間を 要する.

高度鼻呕腔閉鎖機能不全を主症状とする口箩 裂術後の治療法に関する報告は少ない，成書を みても，咽竨弁法と re-push-back 法との簡単 な記武にとどまっている(12)3)。両者と屯前述し たような欠点をむち，適匛症状の重い例には 無理であろう。重症例には軟口蓋の最大限の延

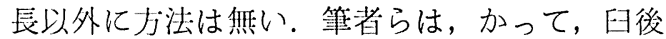
部に茎を持つ長く幅広く煩粘膜弁を两側にと り，乙れを用いてロ蓋骨後端を全居離断した間

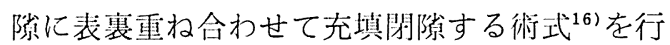
ったととがあったが， 田画部添加成長期以降の 年秢例において, しばしば弁の壊死をきたし, 結果は落胆したものであった。

现在口蓋裂一次手術の成績はきわめて良好で あり，通常の手術によって高度な鼻栶腔閉鎖機 能不全をきたすの例は全くないといってよい成 績が示されている，高度な不全例は粘㸝下口蓋 裂や先天性に機構上の異常がみとめられる例に おいてみられるむのだと断言できるほどであ る、したがって，口蓋裂手術はそれによっても たらされる上顎の発育障害をいかに防止するか という点に手術法の改良がなされつつある．顎 発育ばかりにとらわれて言語の成績が芳しくな いような手術は論外であるが, 一般に一次手術 の結果はきわめて良好なのが現状である。こて に述べた高度な不全例は娍少の一途をたごるは 
ずであるが，初回手術の重要さを強調して本稿 を終える。

\section{結 語}

短少にして動きの腎い口蓋裂術後軟口蓋の治 療方法在述べた。!側粘膜弁の最大限の後方移 動は口蓋骨後縁から咽頭側壁に至る鼻側の切開 離断により達せられる。乙れにより生じた鼻側 の組織欠損は栶頭扁桃部に茎をむつ咽頭弁によ り間隙なく被復する．20 mm幅の咽頭弁は $30 \mathrm{~mm}$ 上の展開が容易であり，弁採收部は綐維する。 ここに用いた咽頭弁は咽䫓容積の維少と咽頭側 壁正中移動による咽頭腔閉鎖の補助棈造物とし ての目的を有するものではなく，軟口蓋鼻側の 組織欠損を被㫫するためのものである。したが

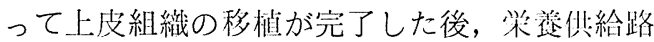
としての茎が欶口蓋の動きを制約するような例 では茎の切断考考朢する。等觔の走行暴常老同 時に処理修復し，後方移動された軟口㦈は，よ り尾側に挙上点を得て鼻咽腔の閉鎖弁としての 構造と機能を持つことになる。

\section{参考文献}

1）赤川㟨弥：口蓋裂の二次修正.チームアプローチ による口蓋裂の治燎（昭和大学口蓋裂誩獠班編）. 138～145頁, 金原出版, 東京, 1983.

2 ) 鬼塚卓弥：口蓋裂手術後の問題点. 形成外科手術 書. 604 608頁, 南江堂, 東京, 1982 .

3 ) Yules RB, et al : Secondary techniques for correction of palatopharyngeal incompetence. Cleft Lip and Palate (ed by Grabb, W.C. et al). 451 489, Little Brown and Company, Boston, 1971 .

4) 木村 照：口蓋裂を伴わない留咽腔閉鎖不全症 32 症例の治燎経験. 耳舁臨床 $70 ： 597 〜 621 ， 1977$.
5 ）岡崎恵子：口蓋裂言語の治療.チームアプローチ に上る口篮裂治療（昭和大子口蓋裂彰燎班編）. 171 174頁, 金原出版, 東京, 1983.

6) Bzoch KR : Categorical aspects of cleft palate speech. Cleft lip and palate (ed by Grabb, W.C. et al). 713 733, Little Brown and Company, Boston, 1971.

7 ）山田美代子，川野通夫：唇裂口蓋裂の手術と言語 指導の奏態. 耳帠臨床 74 : 1495 1498, 1981.

8）川野通夫，一色信彦：口蓋裂の言語指導. 耳宜臨 床 $74: 1491 \sim 1508,1981$.

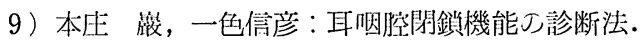
耳舅臨床 $64 ： 853 \sim 861 ， 1971$.

10）本庄 菛：口蓋裂音声における䁷咽腔閉鎖度の意 義. 耳鼻臨床 $60 ： 865 \sim 881 ， 1967$.

11) Fara $M$, et al : Primary pharyngofixation in cleft palate repaire. PRS 45:449 458, 1970.

12) Isshiki $\mathrm{N}$ and Morimoto $\mathrm{M}: \mathrm{A}$ new folded pharyngeal flap. PRS 55:466, 1975.

13）平本道昭，他：折り畳み咽頭弁手術手技の 2.3 . の土夫について. 耳帠臨床 $76: 731 \sim 735 ， 1983$.

14）平野 奏：簡便で有效な push back operation. 耳非 $20: 461 \sim 462,1974$.

15）川野通夫，他：レ線造影ビデオ梌査法の言語治燎 による意義. 耳鼻臨床 $76: 785 \sim 792,1983$.

16）西村善彦，他：口蓋裂二次手術失敗例の反省. 日 形会誌 $4: 767,1984$.

17）一色信彦：口蓋裂の基礎的臨床的研究. 日形会誌 $2:$ 589 590, 1982.

18）本庄 激, 他：口翼裂手術における挙筋索形成の 意義. 耳舅臨床 $73: 33 \sim 36,1980$.

\section{別刷請求先：西村善彦} T663'西宮市武庫川町 $1-1$ 兵庫医科大学耳鼻咽喉科学教室 